\title{
PEMBUATAN BIOGAS DARI LIMBAH CAIR PABRIK TAHU DENGAN TINJA SAPI
}

\author{
Dewi Ayu Trisno Wati ${ }^{* \star}$ ) dan Sugito *).
}

\begin{abstract}
ABSTRAK
Degradasi bahan organik di bawah kondisi anaerobik menghasilkan campuran gas metana dan karbondioksida. Meningkatnya limbah kotoran sapi dan limbah cair industri tahu dapat dipadukan untuk membuat biogas. Permasalahan dalam penelitian ini adalah berapakah tekanan produk biogas pada perbandingan campuran bahanyang berbeda-beda, dan berapa lama produksi gas yang dihasilkan untuk tiap variasi percobaan. Tujuan dari penelitian ini yaitu untuk mengkaji variasi komposisi, mengukur waktu proses fermentasi dan mengukur tingkat kenaikan tekanan gas yang dihasilkan. Penelitian ini dilakukan 3 variasi dengan pengulangan sebanyak 3 kali yaitu variasi 1 dengan perbandingan 10\% tinja sapi dan 90\% limbah cair industri tahu, variasi 2 dengan perbandingan $25 \%$ tinja sapi dan $75 \%$ limbah cair industrib tahu, variasi 3 dengan perbandingan 50\% tinja sapi dan 50\% limbah cair industri tahu. Percobaaan dilakukan dengan menggunakan reaktor biogas yang terbuat dari drum. Alat yang digunakan untuk mengukur tekanan gas yang dihasilkan yaitu berupa kolom air yang diukur dalam satuan milimeter. Pengukuran waktu fermentasi menggunakan alat ukur jam/stopwatch dengan satuan waktu (jam). Untuk mengetahui perbedaan kekentalan dari komposisi variasi yang telah dibentuk maka dilakukan pengujian kadar air dengan metode gravimetri. Dari hasil penelitian, tekanan gas yang paling tinggi terjadi pada komposisi $50 \%$ tinja sapi dengan 50\% limbah cair industri tahu yaitu antara 29-32 mm kolom air membutuhkan waktu sekitar 96-99 jam untuk menghasilkan gas paling besar. Rata-rata nilai kadar air yang dihasilkan untuk kategori cair sebesar $83 \%$, kategori sedang sebesar 72\% dan kategori kental sebesar $53 \%$.
\end{abstract}

Kata Kunci : Biogas, Limbah Cair industri Tahu, Perbandingan Campuran, Tekanan Gas.

\section{PENDAHULUAN}

Energi merupakan kebutuhan yang penting dalam aktifitas manusia. Energi alternatif yang dapat digunakan pada umumnya yaitu biogas. Energi biogas ini lebih aman dibanding gas elpiji yang mampu menghasilkan ledakan. Pembuatan digester biogas merupakan kendala dalam penerapan penghasilan biogas untuk dimanfaatkan oleh masyarakat. Mahalnya biaya material dan pembuatan unit biogas yang dirasakan tidak sebanding dengan nilai tambah yang diperoleh, sementara itu sumber energi seperti kayu bakar dan minyak tanah lebih mudah diperoleh dan lebih murah (Singh, R.K and Misra, 2005). Industri tahu sebagai salah satu pengolah bahan pertanian menghasilkan produk samping limbah berupa limbah cair (whey/kecutan) dan limbah padat (ampas). Limbah cair tahu sisa produksi memiliki kandungan bahan organik berupa

protein, karbohidrat, lemak dan minyak. Beberapa bahan ini dapat dimanfaatkan untuk energi alternatif. Namun kenyataannya, kebanyakan industri tahu langsung membuang limbah cairnya ke sungai dan sawah sedangkan ampasnya untuk makan ternak. (Setyadi, Nanda dan Sri Rahayu, 2011).
Pemanfaatan limbah cair tahu untuk sumber biogas dengan menggunakan filter anaerobik telah dilakukan oleh Rizkiyah Dewi dan Sakinah (2008). Pembuatan biogas sementara ini diproduksi menggunakan bahan tunggal, oleh karena itu dengan adanya keinginan untuk memanfaatkan limbah cair yang diolah secara bersamaan dengan tinja sapi, maka dalam penelitian kali ini biogas yang diproduksi merupakan dari bahan campuran. Dengan tujuan agar kedua bahan tersebut dapat dimanfaatkan sebagai bahan penghasil bahan bakar alternatif.

Permasalahan dalam penelitian ini adalah bagaimana pembuatan biogas dari limbah cair pabrik tahu dengan tinja sapi dapat dilakukan? Agar permasalahan dalam penelitian ini tidak meluas, maka dibuat batasan-batasan sebagai berikut, yaitu:

\footnotetext{
**) Mahasiswa Teknik Lingkungan

*) Dosen teknik Lingkungan

Universitas PGRI Adi Buana Surabaya
} 
menggunakan limbah cair industri tahu yang berasal dari sisa pencucian setelah terjadi penggumpalan dan menggunakan tinja sapi segar dari hewan sapi ternak. Disamping itu penelitian ini bertujuan mengukur tingkat kenaikan pembentukan biogas per hari dari limbah cair industri tahu dengan tinja sapi; mengukur waktu proses fermentasi untuk menghasilkan biogas secara optimal dari limbah cair industri tahu dengan tinja sapi dan mengkaji variasi komposisi bahan yang lebih efektif berdasarkan perbandingan \% volum antara limbah cair pabrik tahu dengan tinja sapi yang mampu menghasilkan gas metan secara maksimal. Kontribusi penelitian ini bagi masyarakat yaitu sebagai informasi dalam pembuatan biogas berbahan campuran tinja sapi dengan limbah cair tahu, bagi instansi terkait dapat menghimbau para pemilik industri dan peternak dapat memanfaatkan limbah cair tahu dengan tinja sapi sebagai bagan penghasil biogas sekaligus dapat dimanfaatkan sebagai pupuk cair.

Jumlah limbah cair yang dihasilkan oleh industri pembuat tahu kira-kira 15-20 I/kg bahan baku kedelai, sedangkan bahan pencemarnya kira-kira untuk TSS sebesar $30 \mathrm{~kg} / \mathrm{kg}$ bahan baku kedelai, BOD 65 $\mathrm{g} / \mathrm{kg}$ bahan baku kedelai dan COD 130 $\mathrm{g} / \mathrm{kg}$ bahan baku kedelai (EMDI \& BAPEDAL, 1994). Bio gas secara tidak langsung juga bermanfaat dalam penghematan energi yang berasal dari alam, khususnya sumber daya alam yang tidak dapat diperbaharui (minyak bumi). Kumpulan mikroorganisme umumnya bakteri, terlibat dalam transformasi senyawa komplek organik menjadi metan. Lebih jauh lagi, terdapat interaksi sinergis antara bermacam-macam kelompok bakteri yang berperan dalam penguraian limbah. Keseluruhan reaksi dapat digambarkan sebagai berikut Senyawa Organik $\longrightarrow \mathrm{CH}_{4}+$ $\mathrm{CO}_{2}+\mathrm{H}_{2}+\mathrm{NH}_{3}+\mathrm{H}_{2} \mathrm{~S}$ Sejumlah besar bakteri anaerobik dan fakultatif (seperti: Bacteroides, Bifidobacterium, Clostridium, Lactobacillus Streptococcus) terlibat dalam proses dan fermentasi senyawa organik Dapat dilihat pada Gambar 2.2 berikut ini:

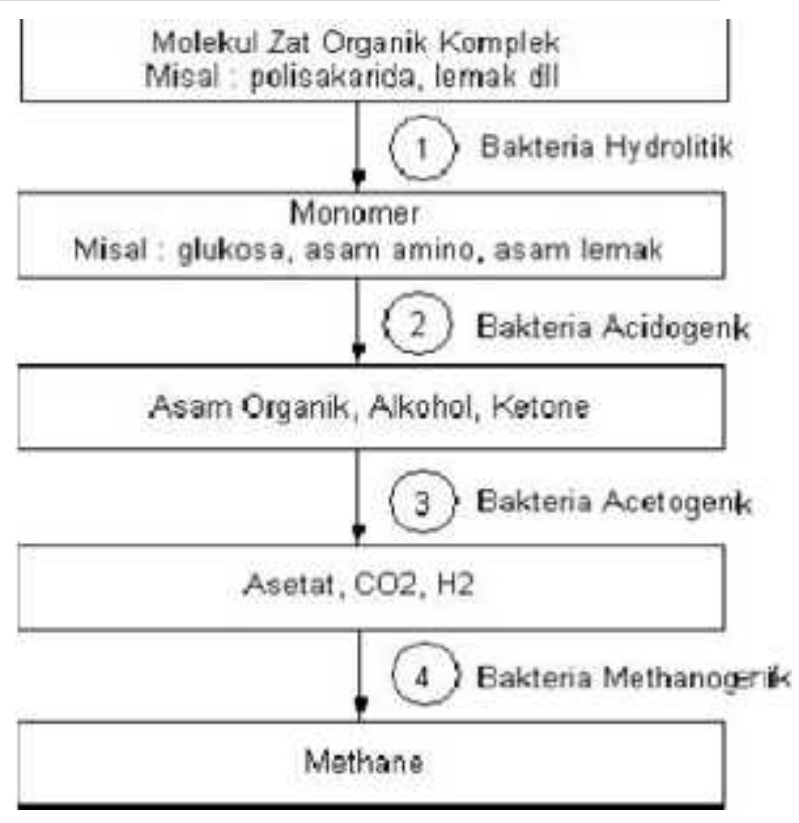

Gambar 1. Kelompok Bakteri Metabolik yang terlibat dalam penguraian limbah dalam sistem anaerobik.

Kotoran sapi pada umumnya banyak mengandung air dan nitrogen (N). Kotoran sapi merupakan substrat yang paling cocok untuk pemanfaatan biogas. Substrat dalam kotoran sapi telah mengandung bakteri penghasil gas metana.

\section{METODE PENELITIAN}

\begin{tabular}{lll}
\multicolumn{4}{c}{ Penelitian yang dilakukan } & adalah \\
penelitian & eksperimental, & dengan \\
menggunakan & variabel bebas & dalam \\
penelitian ini & adalah banyaknya & persen \\
komposisi & masing-masing & bahan \\
Sedangkan variabel terikat & dalam
\end{tabular} penelitian ini adalah tekana gas yang dihasilkan menggunakan alat ukur kolom air, waktu yang dibutuhkan proses fermentasi dengan menggunakan alat ukur waktu jam/stopwatch dengan satuan waktu (jam). Alat bantu takar yang digunakan yaitu gayung plastik dengan volume ukur \pm 1 liter. Peralatan dan bahan yang digunakan dalam penelitian ini, yaitu:

a) Reaktor (degester) yang terdiri dari bak pencampur, bak (corong) pemasukan bahan, bak pencerna dan pipa keluaran.

b) Alat pengaduk dan pengukur tekanan (kolom air dengan satuan $\mathrm{mm}$ kolom air)

c) Alat pengukur waktu (jam/stopwatch) dengan satuan waktu (jam)

d) Bahan yang digunakan terdiri dari limbah cair pabrik tahu dengan tinja sapi. 
Dewi Ayu Trisnowati \& Sugito : Pembuatan Biogas Dari Limbah Cair Pabrik Tahu Dengan Tinja Sapi

Berikut adalah reaktor biogas skala rumah tangga yang terbuat dari drum seperti yang terlihat pada gambar 3.2 dan 4.1 berikut ini:

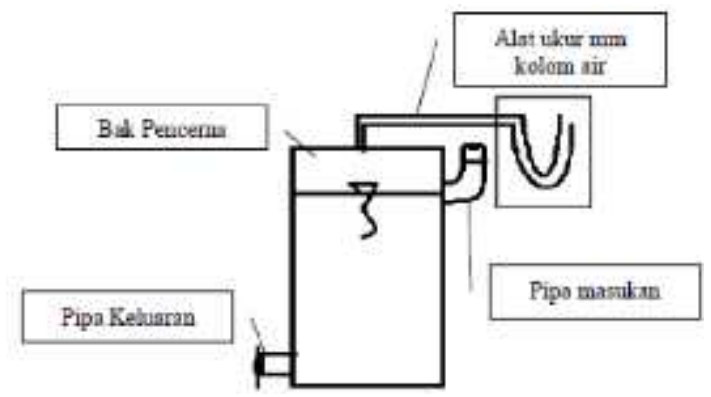

Gambar 2. Digester Sangat Sederhana (DA)

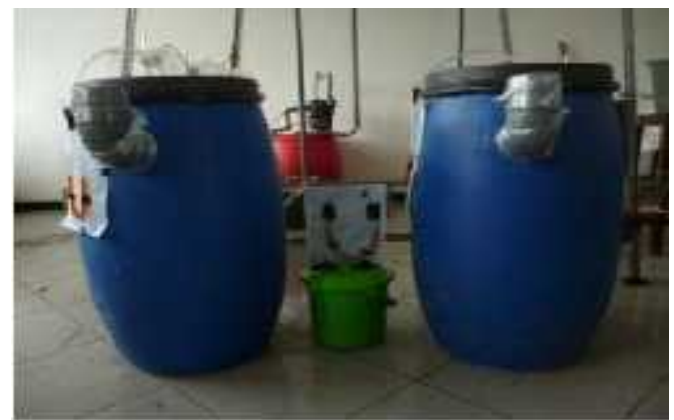

Gambar 3. Model Reaktor (drum biru) dan Reaktor Kontrol (ember hijau)

Langkah kerja pembuatan biogas adalah sebagai berikut:

1. Menakar tinja pada bak pencampur dengan menggunakan alat takat gayung plastik yang berukuran 1 liter.

2. Menambahkan limbah cair tahu dengan bagian penetuan kadar air yang dilakukan dalam penelitian ini.

secara gravimetri sesuai dengan acuan

Standards Methods $21^{\text {st }}$ Edition, 2005 part $2540 \mathrm{G}$.

\section{HASIL PENELITIAN}

Penelitian yang dilakukan menghasilkan data yang kemudian diolah secara grafik maupun tabel. Hasil yang diperoleh dalam penelitian adalah sebagai berikut:

\section{Hasil Kadar Air}

Penelitian yang dilakukan menghasilkan suatu nilai kadar air yang disajikan dalam bentuk tabel sesuai Tabel 1 berikut ini:

Tabel 4.1 : Kadar Air Tiap Variabel Bebas

\begin{tabular}{llll}
\hline No & Kategori & $\begin{array}{l}\text { Perbandingan material (cair : } \\
\text { tinja) }\end{array}$ & Rata-rata kadar air \\
\hline 1 & Variasi 1 & $\begin{array}{l}10 \% \text { Tinja Sapi : } \\
90 \% \text { Limbah cair }\end{array}$ & $81,98-84,97 \%$ \\
2 & Variasi 2 & $\begin{array}{l}25 \% \text { Tinja Sapi : } \\
75 \% \text { Limbah cair }\end{array}$ & $70,98-72,99 \%$ \\
3 & Variasi 3 & $\begin{array}{l}50 \% \text { Tinja Sapi : } \\
50 \% \text { Limbah cair }\end{array}$ & $50,99-54,87 \%$ \\
\hline
\end{tabular}

Berdasarkan Tabel 1.tersebut dapat dikaji untuk mengetahui kadar air dari tiap variasi perbandingan campuran antara limbah cair industri tahu dengan tinja sapi. Dari tabel diatas didapat data bahwa kadar air rata-rata pada variasi 1 (cair) yaitu sebesar $83,31 \%$, kadar air rata-rata pada variasi 2 (sedang) yaitu sebesar $72,29 \%$, dan kadar air rata-rata pada variasi 3 (kental) yaitu sebesar $52,62 \%$.

\section{Hasil Tekanan Gas Maksimal Untuk} Tiap Variasi

Untuk mengetahui variasi mana yang memiliki tekanan gas yang paling optimal dari semua variasi yang ada (variasi 1 , variasi 2 , variasi 3 ), maka perlu adanya analisa data yang membahas dan menjabarkan tentang tekanan gas yang paling tinggi dalam setiap kali percobaan dengan lama waktu selama tujuh hari untuk setiap variasi yang diolah. Berikut adalah tabel 2 tekanan gas paling maksimal untuk tiap variasi pada setiap kali percobaan; 

Sapi

Tabel 2 : Tekanan Gas Maksimal Untuk Tiap Variasi

\begin{tabular}{|c|c|c|c|c|}
\hline \multirow[t]{2}{*}{ Kategori } & \multicolumn{3}{|c|}{ Tekanan Gas Maksimal (mm kolom air) } & \multirow[t]{2}{*}{ Rentang } \\
\hline & $\begin{array}{l}\text { Pengulangan } \\
\text { I }\end{array}$ & $\begin{array}{l}\text { Pengulangan } \\
\text { II }\end{array}$ & $\begin{array}{l}\text { Pengulangan } \\
\text { III }\end{array}$ & \\
\hline Variasi1 & 4 & 5 & 4 & $4-5$ \\
\hline Variasi2 & 18 & 12 & 12 & $12-18$ \\
\hline Variasi3 & 30 & 29 & 32 & $29-32$ \\
\hline
\end{tabular}

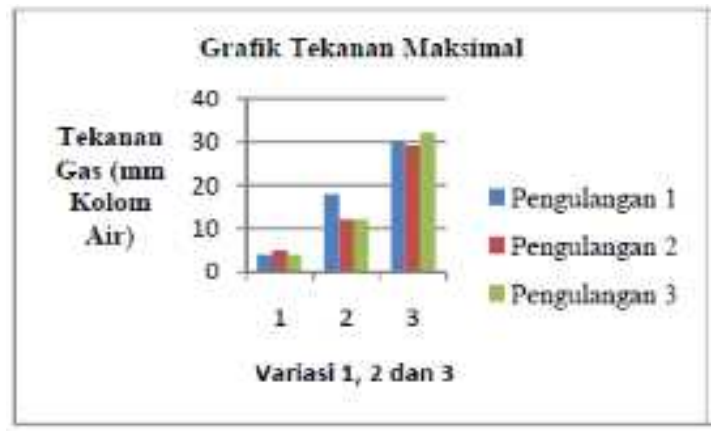

Gambar 4. Diagram Batang Tekanan Gas Maksimal untuk Tiap Variasi

Dari hasil penelitian dapat dilihat bahwa variasi 3 mampu menghasilkan tekanan yang maksimal hal ini sesuai dengan kondisi campuan yang seimbang dengan kekentalan yang seimbang sehingga kadar air yang dimiliki dapat berfungsi dengan baik dalam tahapan hidrolisis campuran tinja sapi dengan limbah cair pabrik tahu. Reaksi yang berlangsung yaitu :

$\mathrm{CH}_{3} \mathrm{CH}_{2} \mathrm{COOH}+0,5 \mathrm{H}_{2} \mathrm{O} \rightarrow 1,25$
$\mathrm{CO}_{2}+1,75 \mathrm{CH}_{4}$

3. Hasil Lama Waktu Produksi Gas untuk Tiap Kategori Waktu merupakan salah satu parameter penting dalam penelitian ini. Tujuannya adalah untuk mengukur berapa lama waktu yang dibutuhkan guna menghasilkan gas pada setiap variasi limbah tahu yang diolah. Sehingga untuk mengetahui variasi mana yang membutuhkan waktu paling cepat untuk menghasilkan gas dengan tekanan yang paling tinggi, maka perlu adanya analisis data yang membahas tentang tekanan gas yang paling tinggi dalam setiap kali percobaan dengan lama waktu selama tujuh hari untuk setiap variasi yang diolah. Berikut Tabel 4.6 adalah tabel lama waktu yang dibutuhkan untuk menghasilkan gas dengan tekanan yang paling tinggi untuk tiap variasi pada setiap kali percobaan;

Tabel 3 : Waktu Proses Gas untuk Tiap Kategori

\begin{tabular}{lccccc}
\hline Kategori & \multicolumn{2}{c}{ Waktu Produksi Biogas (Jam Ke-) } & \multicolumn{2}{c}{ Rentang } \\
\cline { 2 - 4 } & Pengulangan I & Pengulangan II & Pengulangan III & \\
\hline Variasi1 & 113 & 115 & 96 & $96-115$ \\
Variasi2 & 113 & 97 & 96 & $96-113$ \\
Variasi3 & 99 & 97 & 96 & $96-99$ \\
\hline
\end{tabular}

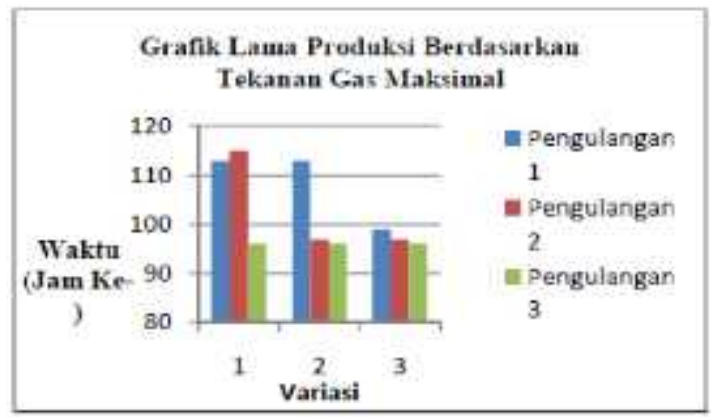

Gambar 5. Diagram Batang Lama Produksi Berdasarkan Tekanan Gas Maksimal
Dari hasil pengamatan Tabel 3 dan

Gambar 5, dapat dilihat jelas bahwa kondisi kadar air mampu mempengaruhi lama waktu proses fermentasi pembentukan biogas. Dimana kadar air yang tinggi dengan kondisi encer (variasi 1) lebih lama dibanding kondisi campuran kental (variasi 3).

\section{Hasil Gabungan Tekanan Gas Harian untuk Tiap Variasi}

Untuk mempermudah dan memperjelas pembahasan, maka
perlu adanya anasilis data gabungan mulai dari waktu dan tekanan dari semua kategori 

Sapi

limbah yang diolah selama penelitian berlangsung. Yang disajikan di bawah ini merupakan data gabungan tekanan gas harian untuk tiap variasi dimana data yang diambil merupakan tekanan gas saja untuk tiap variasi, dimulai dari hari pertama sampai hari ke tujuh.

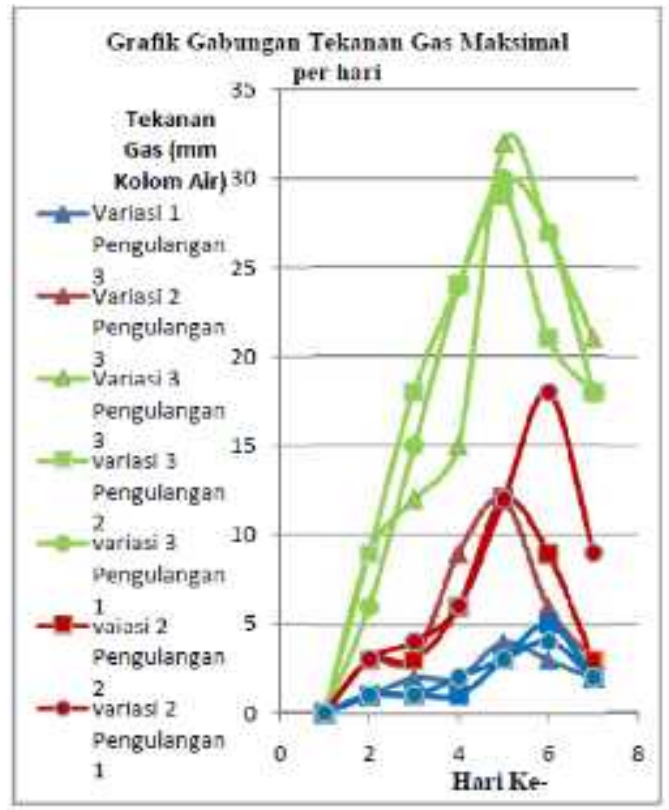

Gambar 6. Grafik Gabungan Tekanan Gas Harian Pengulangan 1, 2 dan 3

Dengan memperhatikan hasil Gambar 6, maka dapat dijelaskan bahwasannya tekanan gas yang paling maksimal dan waktu yang dibutuhkan paling cepat untuk menghasilkan gas tersebut diantara ke tiga variasi yang ada.

Selama penelitian dilakukan adalah terjadi pada limbah cair tahu dengan tinja sapi yaitu variasi 3 , dimana tekanan gas yang paling maksimal terjadi pada hari ke lima dengan besar tekanan antara 29-32 mm kolom air. Karena kandungan padatan yang cukup serta kandungan bahan organik yang sesuai dengan kebutuhan mikroba, sehingga mikroba dapat tumbuh dan bekerja secara efektif dan optimal untuk mendegradasi limbah serta menghasilkan gas. Dan kadar air yang seimbang mampu mempermudah proses pemecahan dan pembentukan gas metan secara maksimal.

\section{Hasil Gabungan Tekanan Mimimum untuk Setiap Variasi}

Untuk mengetahui variasi mana yang memiliki tekanan gas yang paling minimum dari semua variasi yang ada (variasi 1 , variasi 2 , variasi 3), maka perlu adanya analisa data yang membahas dan menjabarkan tentang tekanan gas yang paling minimum dalam setiap kali percobaan dengan lama waktu selama tujuh hari untuk setiap variasi yang diolah. Berikut adalah tabel $\mathbf{4}$ tekanan gas paling maksimal untuk tiap variasi pada setiap kali

Tabel 4 : Tekanan Gas Minimum Untuk Tiap Variasi

\begin{tabular}{cccccc}
\hline Kategori & \multicolumn{4}{l}{ Tekanan Gas Minimum (mm kolom air) } & Rentang \\
\cline { 2 - 5 } & $\begin{array}{l}\text { Pengulangan } \\
\text { I }\end{array}$ & \multicolumn{2}{l}{$\begin{array}{l}\text { Pengulangan } \\
\text { II }\end{array}$} & $\begin{array}{l}\text { Pengulanga } \\
\text { n III }\end{array}$ & \\
\hline Variasi1 & 1 & 1 & 1 & 1 \\
Variasi2 & 3 & 3 & 3 & 3 \\
Variasi3 & 6 & 9 & 9 & $6-9$ \\
\hline
\end{tabular}

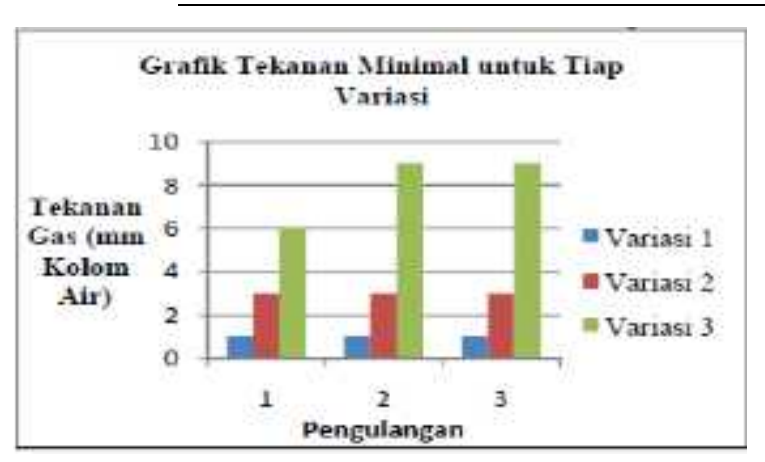

Gambar 7. Tekanan Minimal Untuk Variasi

Berdasarkan Gambar 7 tersebut dapat disimpulkan bahwa untuk variasi 3 dengan jenis bahan kental mampu menghasilkan tekanan minimum yang lebih besar dibanding variasi 1 dan 2 . Hal ini dapat diamati untuk kondisi variasi 1 dan 2 yang mengandung banyak kandungan airnya menyebabkan lebih sedikit hasil keluaran tekanan gas yang dicapai.

\section{PEMBAHASAN}

Berdasarkan hasil analisis data, maka dapat diambil suatu kesimpulan bahwa variasi 3 mampu menghasilkan gas bio paling optimal dibandingkan dengan vairasi campuran lainnya baik dari segi waktu maupun tekanan gas yang 
dihasilkan. Variasi tingkat kekentalan atau variasi kadar air yang ada pada campuran limbah cair tahu dengan tinja sapi ini, sangat mempengaruhi lama waktu yang dibutuhkan untuk memproduksi gas dan berkorelasi sama dengan tekanan gas yang dihasilkan.

Hal ini sesuai dengan teori yang ada dan sudah dipaparkan pada bab kajian pustaka, antara lain: Mikroorganisme metanogen tumbuh secara lambat dalam air limbah dan waktu tumbuh berkisar 3 hari pada suhu $35^{\circ} \mathrm{C}$; jika limbah cair yang diolah menjadi biogas mengandung asam asetat berlebih (dalam penelitian ini terdapat pada limbah variasi 1), maka bakteri asetoklastik (bakteri yang merubah asam asetat menjadi metan) tumbuh jauh lebih lambat dan protein merupakan senyawa organik yang membutuhkan waktu relatif lama untuk didegradasi menjadi gas metan oleh mikroba. Kandungan protein yang paling tinggi dalam penelitian ini terdapat pada campuran limbah cair tahu dengan tinja sapi untuk variasi 1. Tinja sapi yang berumur masih segar (1 hari) mampu mengkontribusi nilai kadar air yang ada, maka sebaiknya menggunakan tinja sapi yang sudah berumur 1-3 bulan. Untuk memastikan bahwa gas yang timbul merupakan gas metan maka dilakukan pemisahan gas $\mathrm{CO}_{2}$ dengan menggunkan larutan kapur.

\section{SIMPULAN DAN SARAN}

\section{A. Simpulan}

Berdasarkan hasil penelitian yang telah dilakukan maka kesimpulannya yaitu tekanan gas yang dihasilkan dari masingmasing digester dengan perbandingan campuran pada kategori yang berbedabeda, menghasilkan tekanan gas yang berbeda-beda pula; lama waktu yang dibutuhkan sampai dengan menghasilkan gas dengan tekanan yang maksimal berbeda-beda pada masing-masing kategori dan limbah cair tahu dengan tinja sapi untuk kategori kental yang mampu menghasilkan gas secara optimal dan efisien dibandingkan kategori encer.

\section{B. Saran}

Saran yang dapat diberikan dari penelitian ini adalah sebagai berikut :

1. Disarankan untuk perlakuan perawatan peralatan biogas, setelah proses fermentasi berlangsung maka residu dan cairan dapat dimanfaatkan sebagai pupuk organik baik cair ataupun padat. Sehingga memiliki nilai ekonomis lebih lanjut.

2. Menyarankan agar setelah pelaksanaan proses pembuatan biogas maka residu dan cairan dapat dikeluarkan melalui pipa keluaran dengan kondisi reaktor sedikit dimiringkan, agar residu yang masih tersisa lebih mudah dikeluarkan.

3. Disarankan untuk reaktor tidak terdapat ruang yang kosong dan berlubang yang akan menjadi ruang bagi udara berkurang sehingga tekanan gas yang dihasilkan tidak maksimal. Sebaiknya alat ini tidak digunakan dalam kondisi hujan, dikhawatirkan air dapat masuk dalam box.

\section{DAFTAR PUSTAKA}

Anonymous.http://jurnal-peternakan.blogspot.com/2010/09/membuat-kompos-dengan-kotoran sapi.html\#.UTbDANbwl1w (Diunduh tanggal 1 Maret 2013).

Anonymous. http://onlinebuku.com/2009/01/15/limbah-tahu-cair-menjadi-biogas (Diunduh tanggal 27 Juli 2013).

Anonymous.http://www.indosiar.com/fokus/limbah-tahu-gantikan-gas-elpiji-96056.html (Diunduh tanggal 27 Juli 2013).

Anonymous. www.kelair.bppt.go.id (Diunduh tanggal 27 Juli 2013).

D., Andrew, Lenore, S., dkk. 2005. Standards Methods for The Examination of Water and Wastewater 21st Edition

Dewi, Rizkiyah dan Sakinah. 2008. Pemanfaatan Limbah Cair Tahu untuk Sumber Biogas dengan Menggunakan Filter Anaerobik. http://digilib.its.ac.id/public/ITS-Master-207292410201007-Chapter.pdf (Diunduh tanggal 28 Pebruari 2013)

EMDI dan BAPEDAL. 1994. Limbah Cair Berbagai Industri Di Indonesia: Sumber, pengendalian dan baku Mutu. Project of the

Ministry for the Environment, Republic of Indonesia and Dalhousie University, Canada.

Rohsari, Amalia Indah Utami. 2010. Peranan Tetes Tebu Dalam Produksi Biogas Sebagai Zat Aditif Dalam Pembutan Biogas dari 
Dewi Ayu Trisnowati \& Sugito : Pembuatan Biogas Dari Limbah Cair Pabrik Tahu Dengan Tinja Sapi

Kotoran Sapi. http://digilib.its.ac.id/public/lTS-Master-15978-1108201007Presenta-tion.pdf (Diunduh tanggal 28 Februari 2013).

Setyadi, Nanda dan Sri Rahayu. Pembuatan Biogas Dari Limbah Olahan Kedelai Menggunakan Digester Skala Home Industri. http://digilib.its.ac.id/public/lTSNonDegree-17094-2308030010-Presenta-tion.pdf (Diunduh tanggal 28 Pebruari 2013).

Singh, R.K and Misra, 2005, Biofels from Biomass, Department of Chemical Engineering National Institue of Technology, Rourkela 